\title{
Perspective and Subjectivity: The Power of Images in Northamerican Short-Story Writing
}

\author{
María Rosa Burillo Gadea \\ Universidad Complutense de Madrid, Madrid, Spain
}

\begin{abstract}
The study is meant to describe the evolution of American short-story writing with patterns where visual images have become central and not peripheral for the understanding of stories. Hemingway's use of objective correlatives was a trace mark, and the literary editors at The New Yorker urged their writers to slow down the emphasis on movement and plot in order to recreate a certain mood which would favour the perception of objects, anecdotes, and details. The impressionistic device works very much in the same way that an advertisement would do. It is meant to persuade the audience. The apparently non-commitant vision of reality shows in fact the author's point of view. The apparent simplicity is meant for a very wide audience and its deepest meaning suggests the scope of the particular visual aids working at the deepest level of consciousness.
\end{abstract}

Keywords: images, detachment, view-point, subjectivity, passion, effect

\section{Introduction}

There is a kind of detachment which is proper of the short-story as gender, it implies (it gives the illusion) that the information given is precise, that the narrator is not interested in life being one way or another, and that he is going to describe facts as they happen to be. Apparently there is no doubt of his objectivity, there is no explicit judgement of the situation, and he avoids recreating feelings, but the very selection of images speaks for themselves on behalf of the author. It is encapsulated meaning.

Let us consider the description of a photograph in Hemingway's story “Soldier's Home”. The protagonist, a soldier, enlisted in the Marines second division, is sent to war in Europe:

There is a picture which shows him on the Rhine with two German girls and another corporal. Krebs and the corporal look too big for their uniforms. The German girls are not beautiful. The Rhine does not show in the picture. (Hemingway, 1977, p. 224)

The Objective Correlative, as T. S. Eliot named this kind of writing, provides the pure emotion through a situation. The absence of explanation or comments is intended. It is meant to impress the reader's mind with the impact of perception. As the picture shows the uniforms are tightening the men wearing them, the girls defy the standards of beauty, traditionally associated to the glory of war, and the river, Nature itself, is missing, as if refusing to take part in the masquerade. Underneath lays the author's perspective of the war as a gigantic lie. The

María Rosa Burillo Gadea, Ph. D., Universidad Complutense de Madrid. 
whole construction is mocking at the "Objective Universal Morality" (Lakoff \& Johnson, 1999, p. 554), the set of values perpetuated by tradition.

\section{Visual Images}

Rather than the development of an argument or the evolution of characters, which is typically the concern of a novel, a short-story resolves itself around images. Literary editors at The New Yorker, like William Maxwell and Gus Lobrano are responsible for structural patterns where a situation is conceived around relevant details and other visual effects. The fictional time has been manipulated, and the narrative is shown in a kind of slow-motion rhythm in order to fix the attention of the public in objects and things that really matter.

Therefore, the action does not depend on the evolution of plot, which is quite irrelevant, since it only describes the present condition of humanity with its lack of stimuli or achievement. The selected images engross meaning in quite a different way. As Carver suggested:

It's possible, in a poem or a short-story, to write about commonplace things and objects using commonplace but precise language, and to endow those things—a chair, a window curtain, a fork, a stone, a woman's earring — with inmense, even startling power. It is possible to write a line of seemingly innocuous dialogue and have it send a chill along the reader's spine_the source of artistic delight, as Nabokov would have it. That's the kind of writing that most interests me. (Carver, 1983, p. 15)

The stories mirror contemporary life, and they give the illusion of objectivity necessary to convince the audience that the characters are very much like the readers themselves. They are lonely people, unable to communicate and with no purpose in life. They recreate an atmosphere of stagnation and nostalgia, the appropriate mood for the perception of "the senses" (Clarke, 1990, p. 101), the true repository of the emotions suggested.

The device proves efficient since it is only through sensation that people are moved, and a reader has to be moved in order to be convinced. Images and details are responsible for the arousal of passion, and it is only through passionate feelings that readers may change. Conventional arguments then become irrelevant as their only purpose is identification with the audience, but the real homeliness that Poe wrote about, the true empathy of the senses, lays already there, is spiritual, and goes far beyond entertainment. The aim is to get readers hookwinked or taken, as Cheever once said, and for the purpose of active communication which is the essence of Cognitive Science: "Because our conceptual systems are mostly unconscious and neurally fixed, conceptual change is at best slow and difficult. We cannot freely change our conceptual systems by fiat” (Lakoff \& Johnson, 1999, p. 556).

It is the same appeal used in advertizing, and it is there for the same purpose. The aim is to make an impact on the audience and to produce an effect. Perfectly aware of the strategies of persuasion, "the writers authorizing 'eye”" (Ford, 2007, p. xix) takes good care in an efficient use of metaphors. As statistics show, "literature provides the highest rate of metaphorical use, poetry stands first with $56 \%$, and there goes modern fiction with 28\%. Advertising follows with some 22\%...” (Goatly, 1997, p. 312). One ought to remember that stories are there in the same magazine, in unfair competition with colourful advertisements, and literary authors have to govern themselves accordingly if they want to gain the interest of the reading public: "In publishing in a magazine you are competing against girdle advertisements, nakedness, cartoons, even poetry” (Collins, 1982, p. 97). 


\section{Sample I: What We Talk About When We Talk About Love}

Samples of Carver's "What We Talk About When We Talk About Love" (1981) show that the apparent objectivity, the slow-motion is there to captivate the audience, so that they may become impressed by the dominant images which suggest, without explanation, the real view-point of the author, the sort of impression that he means to communicate. The characters are two couples, they seem to be close friends, and they are having drinks around a kitchen table, the kind of domestic atmosphere that a middle class audience identifies. The situational metaphor shows the origin of the conflict, the typical loneliness of people forced to make their living in the artificial environment of city life and suburbia, and the panorama of contemporary America as we know it, its particular unrootedness: "We lived in Alburquerque then. But we were all from somewhere else" (Carver, 1996, p. 170), stressing the fact of their problematic position in life: "Although indigenous Americans are not inmigrants, they have also experienced dislocations that can properly be considered diasporic...” (Elliott, 2007, p. 15).

The conventional metaphors are there to remind the readers that we all participate of tradition, the same familiar patterns of right and wrong. Within the group of friends Mel McGinnis becomes the central figure since it is around him that most of the discourse takes place. We are informed that he is a cardiologist, that he was at the seminary, and that he believes in spiritual love. The conversation that the two couples hold is around love. The typical conventional metaphor becomes a reminder of what has been assumed as a universal truth, that the words cardiologist, medical school, and rightness are part of our objective knowledge, the kind of structural metaphor assumed: "My friend Mel McGinnis was talking. Mel McGinnis is a cardiologist, and sometimes that gives him the right” (Carver, 1996, p. 170).

The mocking effect suggests the view-point of the author himself. He makes the structural metaphors coexist with the selection of images around McGinnis. They are there to reveal the writer's perspective, making fun of the stereotyped, conservative vision of the world. It shows, without saying, that the character's arguments are unreliable, and the pictures suggest McGuinnis's distorted vision of reality.

Let us consider Image 1 . Mel is speaking:

...I'd like to come back as a knight. You were pretty safe wearing all that armor. It was all right being a knight until gunpowder and muskets and pistols came along... what I liked about knights, besides their ladies, was that they had that suit of armor, you know, and they could't get hurt very easy. No cars in those days, you know.... (Carver, 1996, pp. 180-81)

It is fear that best defines McGuinnis as a character. He is frightened by life to the point of non-existence. He'd rather keep himself safely inside an armour. If we push the issue a bit further, it is traditional society that McGinnis most resembles.

Society's armour is made of institutions which are there to force the citizens to lead uninteresting lives, buried under the carcass of obsolescence. The notion of ideal love, a word of absolutes, is part of the conservative thought. Society's standards are carefully preserved. As a knight in his armor, life keeps itself safely imprisoned and refusing to give a chance to information and change. The stagnation is perceived through the senses with the impact that the image forcefully shows.

The idea is also reminiscent of Don Quijote, and it implies society's mental infirmity, paranoia. The reminiscence becomes more powerful when the resources of our cultural memory arise. The information, concise 
and minimal, comes within the scope of the well-informed reader, and relies on interpretation. Ideal communication is then achieved through intuition or "homeliness" (Poe, 1994, p. 1535).

Then the counter argument shows the view-point of the narrator, the subjectivity of the author, objectified by pursuing the vision a bit further on:

But sometimes they suffocated in all that armor, Mel. They'd even have heart attacks if it got too hot and they were too tired and worn out. I read somewhere that they'd fall off their horses and not be able to get up because they were too tired to stand with all that armor on them. They got trampled by their own horses sometimes. (Carver, 1996, p. 181)

The whole picture is amplified to make the reader participant of the alternative information, which is also full of suggestions. The fact that it is his horse who may damage and kill the man in the armour brings into focusing the cultural tradition of the West, when a man and his animal used to become one and the same thing in a world full of meaning. Further associations arise, together with the implicit argument that Nature has become deeply wounded. It is even reminiscent of Cooper's Leatherstocking, Natty Bumppo, a defender of the catechism outdoors, as when it says: “I believe there’s some who thinks there’s no God in a wilderness!” (Cooper, 1964, p. 349). Underneath it is Max Westbrook’s auspices that “American narrative is typically west” (Westbrook, 1971, p. 16).

A further discredit to the character is the war-argument metaphor that recurrently occurs along the text, Mel's attitude towards his wife, Terri, the woman he is supposed to be in love with. The agression comes from his firm conviction that they will never be able to achieve ideal love. His decadence and lack of illusion show once and again in Image 2, which becomes a disclosure, a revelation of his inner thoughts. The mistake at the core of the story:

“Bzzzzzzz”, Mel said, turning his fingers into bees and buzzing them at Terri’s throat. Then he let his hands drop all the way to his sides.

"She’s vicious”, Mel said, “Sometimes I think I’ll go up there dressed like a beekeeper. You know, that hat that's like a helmet with the plate that comes down over your face, the big gloves and the padded coat? I'll knock on the door and let loose a hive of bees in the house. But first I’d make sure the kids were out, of course”. (Carver, 1996, p. 184-85)

The response to the mental picture is a profound silence; the story has reached a climatic effect-the discovery that his social carcass is coming to pieces as the dialogue insists: (Mel to Terry) "Just shut up for once in your life”, Mel said very quietly, “Will you do me a favor and do that for a minute?” (Carver, 1996, p. 178).

The author's perspective is made evident without further comments. Carver has made the point that practical knowledge can never explain the mechanics of love, that McGuinnis's confusion is visualized in the game of words, where vessels and vassals become mixed up restating the confusion of society, its subordination to the norm. Life then is shown as a hierarchical organization of vassals, its game a continuous struggle for dominance and power:

"Vassals, vessels,” Mel said, “what the fuck’s the difference? You knew what I meant anyway. All right,” Mel said. "So I'm not educated. I learned my stuff. I'm a heart surgeon, sure, but I'm just a mechanic. I go in and I fuck around and I fix things. Shit,” Mel said. (Carver, 1996, p. 181)

His wife's role is very much the same. Her love relationship is that of a vassal to his master, to either his first or second husband, her mistake lays in the election of the wrong option, romantic love. The objects associated to 
her as characters are superficial and pretentious, a symbol of materialistic standards, and the terms by which she lives: "necklaces made of turquoise, and long pendant earrings" (Carver, 1996, p. 171), the suggestion that fashion is at the core of her thoughts, as Goatly says: "Mechanics, as part of physics, has tried to turn nature into an industrial machine" (Goatly, 2007, p. 393).

The counter argument to the female role is obviously the narrator's wife, she is a legal secretary. She does not say much, but she seems to feel right, true to herself, in a sort of attitude that defies explanatory arguments of any sort, the narrative shows "the power of silence" (Barth, 1995, p. 71), and it is there, right in the middle of the text that we perceive what love should be like.

\section{Sample II: The Country Husband}

John Cheever's "The Country Husband" (1954) shows Francis Weed, the father of a middle class family who lives in the suburb of Shady Hill. The story tells what life is like in the suburban areas around the Hudson River, where the author used to live. The suburbs lay at an hour's distance from the city of New York by train, and commuting is shown in the text as a big metaphor for change, and the same is true of many other stories like "The Angel of the Bridge” (1961) or “ The Five Forty Eight” (1954). The awakening of consciousness takes place away from home, where Cheever's protagonists face different situations or particular incidents.

In "The Country Husband" Francis Weed has been in a plane crash that very morning. The revolving effect of the experience makes a sharp contrast with his actual mood, and to make things worse, nobody seems interested in listening to what he has to say. The incident is there to show the attitude of the suburb which has swept illness and death from their daily lives, as if they were concepts that could be avoided altogether. The tempo of suburbia excludes reality, and all the inhabitants have agreed to exclude life from their surroundings. It is actually a conspiracy to speak nicely, behave nicely, and have the appropriate furniture, neighbours, and friends, these are their only values, what they care for, a pattern which aims to achieve no less than perfection in things public. The nonsensical attitude comes to a climax when in "The Death of Justina" (1960), Moses, American everyman, cannot bury his cousin Justina because it is forbidden to die in that particular area, and therefore living there; they cannot bury their dead, unless they get a special order from the Mayor. The whole incident sharply shows the domain of authority over the laws of Nature.

Francis Weed's wife, Julia, the archtype of nice talk and happy life at the suburbs, has set the house to cope with the world of appearances, and she is proud of it. Francis and Julia's life together goes around this little fabrication that they have arranged for themselves, pretending being their sole ability in life. In the Image, polished, burnished... are words which are very much at the heart of the matter. Instead of giving information on viewpoint, the very metaphor coolly suggests the conventions of their daily routine:

The largest part of the living room centered on a fireplace. On the right were some bookshelves and a piano. The room was polished and tranquil, and from the windows that opened to the west there were some late-summer sunlight, brilliant and as clear as water. Nothing here was neglected; nothing had not been burnished... The hearth was swept, the roses on the piano were reflected in the polish of the broad top, and there was an album of Schubert waltzes on the rack. (Cheever, 1985, p. 386)

The next figure shows the real perception of the family in sharp contrast with the apparent armony and high class of the place. The little children are crying, the eldest daughter is a spoiled teenager who only cares about herself, and Francis's wife keeps acting as if nothing wrong may ever happen. At the light of the situation, true 
communication is never to be achieved, and nobody is on the mood to listen that Francis Weed has almost died in the plane accident that very day.

Let us see Image 2:

Henry claps his hand over little Toby’s mouth. Francis separates the two boys but accidentally pushes Toby into the woodbox. Toby begins to cry. Louisa is already crying. Just then, Julia Weed comes into that part of the room where the table is laid... She does not seem to notice the fracas. "Hello, darling," she says serenely to Francis. "Wash your hands, everyone. Dinner is ready." She strikes a match and lights the six candles in this vale of tears. (Cheever, 1985, p. 387)

The scarce action develops across a pattern of alternate images, where reality sharply contrasts with the refinement that they have made for themselves, and they stand for the social triumph that they encouragely represent. At the light of these convictions their only tragedy would lie in exclusion from social life, barbacues and Friday night parties. The Christmas picture, a sympthom of the intensity that they are truly convinced with, is there for visual effect, as Image 3 suggests:

The children were in their best clothes, and when Julia came down, she was wearing a lavender dress and her diamond sunburst... She had put out Francis' blue suit and a tie with some color in it, because the picture was going to be in color this year. Julia was lighthearted at the thought of being photographed for Christmas. It was the kind of ceremony she enjoyed. (Cheever, 1985, p. 399)

Then, we find that the author's perspective is paradoxical to some extent and the criticism is only half grounded. At heart there is commiseration and even love for the victims of the suburbs. Francis Weed somehow regrets that he cannot wholly participate and he is stunned at the neighbour's confession that true love does exist. The highlighted next image is enriched with mythological reference and shows a nostalgic desire to reaffirm the values of tradition as they used to be: "She’s my girl”, their host said, squeezing his wife. "She’s my blue sky. After sixteen years, I still bite her shoulders. She makes me feel like Hannibal crossing the Alps” (Cheever, 1985, p. 399). The narrator's perspective is shown and it furtherly suggests the author's mixed feelings about the suburbs: "My God, the suburbs! They encircled the city’s boundaries like enemy territories and we thought of them like a loss of privacy, a cesspool of conformity and a life of indescribable dreariness...” (Cheever, 1960, p. 67), and then, Cheever says next:

...if you work in the city and have children to raise, I can't think of a better place. My neighbours are rich, it is true, but riches in this case mean leisure, and they use their time wisely. (Cheever, 1985, p. 294)

Inlikemanner Francis's nostalgia comes from the inner conviction that he has been excluded from life, and criticism of contemporary life is waning at best. It is the very same paradox that Cheever portrays in "Expelled", his first story published by The New Republic in 1930, a longing to be esteemed by the society that he so vividly abhors.

In "The Country Husband" Francis Weed is a dreamer, but he is also a loser. It seems that these two poles can hardly be reconciled. Almost naïve in his appreciation that true love exists, he turns towards Anne Murchison, the babysitter. He finds her irresistable, a perfect mixture of beauty, youth and innocence, he feels lonely, and suffers from uncorresponded love. She is too young and he is married. The stereotype is somehow distorted by the protagonist's singularity that settles him beyond his role. Subtly the story identifies him with highlighted visions of real perfection, and the words associated to Gertrude, to Jupiter, raise the standards to comprehend the 
alternative reality that peculiar beings are the best and only options to life:

Jupiter was an anomaly. His retrieving instincts and his high spirits were out of place in Shady Hill. He was as black as coal, with a long, alert, intelligent, rakehell face. His eyes gleamed with mischief, and he held his head high... He broke up garden parties and tennis matches... He crashed through old Mr. Nixon's rose garden two o three times a day.... (Cheever, 1985, pp. 389-90)

Gertrude was a stray. She had been born with a taste for exploration, and she did not have it in her to center her life with her affectionate parents. People who did not know the Flannerys concluded from Gertrude's behavior that she was the child of a bitterly divided family, where drunken quarrels were the rule. This was not true. The fact that little Gertrude's clothing was ragged and thin was her own triumph over her mother's struggle to dress her warmly and neatly.

The story atributes intelligence to the unconquerable dog and loneliness to the little girl and reaffirms the plea to the world to move beyond the standards. The repeated motto "Go home, Gertrude, Go home" (Cheever, 1985, p. 398) may as well be addressed to Francis Weed, split between his duty to family order, and his love for exploration and the wild. Again, very much like the author himself: "I don't know why such an unconventional man lived such a conventional life, but he meant to" (Cheever, 1991, p. 2).

The very definition that he applies to Gertrude that "She had been born with a taste for exploration" can equally be applied to himself. The narrator's perspective resembles Francis Weed's hidden dreams, a pray to let them be:

A miserable cat wanders into the garden, sunk in spiritual and physical discomfort. Tied to its head is a small straw hat—a doll's hat—and it is securely buttoned into a doll's dress, from the skirts of which protrude its long, hairy tail. As it walks, it shakes his feet, as if it had fallen into water... The last to come is Jupiter. He prances through the tomato vines, holding in his generous mouth the remains of an evening slipper. Then it is dark; it is a night where kings in golden suits ride elephants over the mountains. (Cheever, 1985, p. 410)

The closing glimpse is a daguerreotype of Francis Weed himself, a wish that he is allowed to exist. But when his wife calls, he is promptly there, ready to obey. The end is sad, and we are sorry for Francis, we feel his surrender to family life as his own personal defeat. His revolt is all in his head. As Alfred Kazin once said: “...the pathetic escapade never lasts very long... in these terms the short story becomes not the compression of an actual defeat but the anecdote of a temporary crisis” (Collins, 1982, p. 123). Then, the real aim of the story is not at the end of the trama, and what matters is the force of the visual images, transpassing the boundaries of convention, which stand as their only truth, as alternative stardards to life that Francis Weed, being a loser, will never be able to enjoy, or achieve.

\section{Sample III: Interpreter of Maladies}

Lahiri’s “Interpreter of Maladies” (1999) (Pulitzer Prize 2000) follows the conventional argument of a trip for the day. The Das family, a married couple and three young children, have gone to India, the place of their ancestors, and they hire a tourist guide and a car with the sole purpose of visiting the Sun temple at Konarak. They are very proud that they have been born and raised in America, and they make a point of showing this off. Here and there, selected images show that they are upper middle class. Both Mr. and Mrs. Das share a disdainful attitude towards Mr. Kapasi, the driver of the car, denying the kinship of the race. The situational metaphor describes the issue that will rely on soundful images showing the author's perspective, her subjectivity, restating 
the fact that "When Western ways and those of the homeland are incompatible, as over concepts of privacy, conflict is inevitable and compromise is essential” (Leach, 1997, p. 209).

Mr. Das never speaks to Mrs. Das unless he wants to take a picture of the family. He covers himself under the reading of the tourist guide and behind the lens of his camera; we presume the camera is high quality. Mrs. Das wears a T-shirt with a strawberry drawn upon her chest, an updated version of Hawthorne's Hester Prynne, and this is already a signal, a prelude to her emotional attitude in life. She hides herself at the corner of the car polishing her nails despite the tortuous driving, a soundful image that she is forcing a conventional look in spite of the difficulties. She never says anything; she is practically unaware of the children. When her little girl Nina, aged six, has to go to the toilet, she feels reluctant, avoiding taking her little hand into hers. American detachment is shown as diametrically opposed to Indian's tradition and conceptualization of family life. The author makes a point of showing the evidence through typically American visual aids.

The scene, quite motionless, despite the movement of the trip, reassumes itself around chewing gum, sunglasses, a water bottle, puffed rice, and peanuts. The car seems the technical repository of their empty lives; the objects speak by themselves of convention and routine, the structural metaphor of family life.

The stagnant picture somehow lightens itself when Mrs. Das addresses Mr. Kapasi. His regular job is to be an assistant at a doctor's office, an interpreter of maladies, and Mrs. Das finds it a very romantic quest. A superficial reading would closely follow the plot of the day, but if we pay attention to Image 1 , we feel that like her daughter's doll, she has been deprived of the sweetness of love, her sensitivity forlorn and utterly damaged: "[Nina] She was holding to her chest a doll with yellow hair that looked as if it had been chopped, as a punitive measure, with a pair of dull scissors” (Lahiri, 1999, p. 45).

The description, objective, detached, and apparently unpretentious is the visual prelude to Mr. Kapasi's judgement on Mrs. Das when she confesses to him that her little son, Bobby, is not her husband's child: "Is it really pain you feel, Mrs. Das, or is it guilt?” (Lahiri, 1999, p. 66). The evidence conceptualizes her behaviour in terms of guilt and punishment, and the action might have been mistakenly interpreted as a typical Jeremiad writing in the manner of a Puritan biography such as Mrs. Mary Rowlandson's, but then, Image 2 counter-acts, and prevents trivialization with the vision of grandeur, a tribute to the beauty of life. And the naked women seem to be there an elegy to the unambiguous authority of Nature and truth:

...the three life-sized bronze avatars of Surya, the sun god, each emerging from its own niche on the temple façade to greet the sun at dawn, noon, and evening. They wore elaborate headdresses, their languid, elongated eyes closed, their bare chests draped with carved chains and amulets. The last statue... Around his body were smaller sculptures of women in pairs, their hips thrust to one side. (Lahiri, 1999, p. 58)

The view-point of the author thus remains hinted, unexplained, unambitious, and for a very delicate audience. It is not casual that the son outside marriage is stronger and more independent than the rest, there is a reassurance in the envisage of his presence which contradicts the superficial interpretation of facts.

The last part of the trip, a non-scheduled visit to the monasteries, shows the attack of the monkeys to the illegitimate child, and the final victory of his recovery. The fact that Kapasi is using a branch, reminiscent of the myth in the Bible, as in Cain and Abel, adds spiritual dimension to triviality, and is there to represent the complexity of truth, that conservative Mr. Kapasi is unable to achieve despite his qualities as an interpreter.

Let us see Image 4: 
...he was surrounded by a group of monkeys, over a dozen of them, pulling at his T-shirt with their long black fingers. The puffed rice Mrs. Das had spilled was scattered at his feet, raked over by the monkey's hands. The boy was silent, his body frozen, swift tears running down his startled face. His bare legs were dusty and red with welts from where one of the monkeys struck him repeatedly with the stick he had given to it earlier. (Lahiri, 1999, p. 68)

The utter vision of the woman losing Kapasi's address may be superficially interpreted as another example of the woman's carelessness. Instead what the images subtly prove is that Mr. Kapasi's judgement has become short in understanding the scope of her drama, romantic is the key word, the dream of love that the author's perspective achieves in the election of the image that the wind removes:

Let us see Image 5:

... she reached into her straw bag, this time for her hairbrush, and began to run it around the edges of the translucent visor. When she whipped out the hair-brush, the slip of paper with Mr. Kapasi's address on it futtered away in the wind. No one but Mr. Kapasi noticed. He watched as it rose, carried higher and higher by the breeze, into the trees where the monkeys now sat, solemnly observing the scene below. (Lahiri, 1999, p. 69)

A lot of questions arise: Mr. Kapasi's narrowness of thought is counter-acted by visions suggesting the glory of the natural beauty of women, and the splendor of the wind removing an uninteresting written note. Then, there remains hinted the damage that a world of absolutes may cause to the fine sensibility of a true lady, and the empathy that the narrator feels towards the character. The assertion of her dignity, unexplained but identified through the pictures, provides the real metaphorical meaning to the whole text.

\section{Conclusion}

Rather than a conventional linear plot, the structural pattern is set up in layers and every visual image adds dimension to the whole. Carver's first draft of "What We Talk About When We Talk About Love" was published in 2007 with the original title "Beginners", the extended version (about five thousand words longer) proves that Gordon Lish was right in the omissions at the Knopf edition. As in poetry, effectiveness is typically brief.

True meaning is to be found in the echo left by the images, a reading that is first achieved through the senses. It is only in a state of passion that people are moved. The device mainly follows the strategies of persuasion used in advertising, since stories bear unfair competition with colour pictures within the same magazine. There subtly lays the message of the authors, their real view-point, and the writers' belief that a world of absolutes simply distorts humanity and human emotions very much to the benefit of old-fashioned dogmas.

\section{References}

Barth, J. (1995). A few words about minimalism. In Essays, lectures, and other non-fiction 1984-94 (pp. 71-75). New York: Little, Brown and Company.

Carver, R. (1983). Fires: Essays, poems, stories. Santa Barbara: Capra Press.

Carver, R. (1996). What we talk about when we talk about love. London: The Harvill Press.

Cheever, B. (1991). Private correspondence (unpublished) (pp. 1- 3).

Cheever, J. (1960). Moving out. Squire, 54(1), 67-68.

Cheever, J. (1985). The stories of John Cheever. New York: Ballantine Books.

Clarke, G. (1990). Investing the glimpse: Raymond Carver and the syntax of silence. In The new American writing: Essays on American literature since 1970 (pp.100-116). London: Vision Press.

Collins, R. G. (1982). Critical essays on John Cheever. Boston: G. K. Hall \& Co..

Cooper, J. F. (1964). The pioneers. New York: Signet Classics. 
Elliott, E. (2007). Diversity in the United States and abroad: What does it mean when American studies Is transnational? American Quarterly, 59(1), 1- 22.

Ford, R. (2007). The new granta book of American short story. London: Granta Books.

Goatly, A. (1997). The language of metaphors. New York: Routledge.

Goatly, A. (2007). Washing the brain—Metaphor and hidden ideology. Amsterdam/ Philadelphia: John Benjamins Publishing Company.

Hemingway, E. (1977). Soldier’s home. In C. Skaggs (Ed.), The American short story (pp. 224-229). New York: Laurel.

Lahiri, J. (1999). Interpreter of maladies. London: Flamingo.

Lakoff, G., \& Johnson, M. (1999). Philosophy in the flesh: The embodied mind and its challenge to western thought. New York: Basic Books.

Leach, L. (1997). Conflict over privacy in Indo-American short-fiction. In J. Brown (Ed.), Ethnicity and the American Short Story (pp. 208-234). New York: Garland Publishing, Inc..

Poe, E. A. (1994). The philosophy of composition. In N. Baym, W. Franklin, P. F. Gura, \& A. Krupat (Eds.), The Norton anthology of American literature (pp. 1183-1194). New York: W.W. Norton \& Co..

Westbrook, M. (1971). Conservative, liberal and western: Three kinds of American realism. In J. G. Taylor (Ed.), The literature of the American west (pp.15-24). Boston: Houghton Mifflin Company. 